DOI https://doi.org/10.18551/rjoas.2017-09.16

\title{
INVESTMENT FEASIBILITY ANALYSIS OF MAPPING SURVEY LABORATORY ESTABLISHMENT IN SAMARINDA CITY
}

\author{
Kuswantoro*, Hidayat Sutanto, Santosa Andrianus Agus \\ Study Program of Civil Engineering, Concentration of Construction Management, \\ National Institute of Technology, Malang, Indonesia \\ *E-mail: boengkhoez@gmail.com
}

\begin{abstract}
The rapid growth of construction works in East Kalimantan Province, especially in Samarinda, will also increase the needs of mapping survey equipment availability. The availability of the mapping survey laboratory facility as a supporting facility is expected to accelerate the implementation of a project development in Samarinda and is expected to increase the contribution for the improvement of economic growth in East Kalimantan, especially the capital city of Samarinda, so it is necessary to conduct Investment Feasibility Analysis of Mapping Survey Laboratory Establishment in Samarinda City. The type of research used in this research is qualitative with case study approach because its research produces descriptive data which discuss about investment feasibility assessment by using Net Present Value (NPV) method, Internal Rate Return (IRR), Benefit Cost Ratio (BCR), and Pay Back Period (PBP). The results showed that the investment value of Mapping Survey Laboratory establishment in Samarinda City is Rp.11,619,400,000.00 done in 1 year that is in year of 2016. In the calculation, it obtained total cost and benefits as follows: a) total Cost of Investment + Operational Cost + Credit Bank (Principal Loans + Interest Bank) until 2026 is Rp.20.392.566.497,20, b) benefit from the price of the service until 2026 is Rp.31.574.759.134,50. Mapping Survey Laboratory Establishment is economically feasible to build, with economic analysis as follows: a) Net Present Value Value $>0$ is Rp 1.964.475,890, b) Internal Rate of Return $>12 \%$ is $13,37 \%$, c) Benefit Cost Ratio $>1$ is 1.962 , d) Pay Back Period (PBP) is 4 Years 8 Months.
\end{abstract}

\section{KEY WORDS}

Investment, feasibility, laboratory, mapping, survey.

Acceleration of development in East Kalimantan Province must be supported by the availability of infrastructure or the availability of adequate supporting facilities. The availability of the construction industry as a tool of development, as well as a means of meeting the needs of development itself. Samarinda as the capital city of East Kalimantan Province, geographically, is very strategic, because it becomes the node point of the surrounding city or regency, namely: Tenggarong, Bontang, and Sangata. Samarinda becomes the central point of the land, sea, and air transportation routes making Samarinda as a service city, trade industry, and environmentally settlement.

In the stages of construction work, both in the planning stage and the implementation stage, it requires equipment that supports for data accuracy, (Buchholz et al, 1996). The needed equipment is in line with the needs of the construction itself where the equipment used as needed both from manual model and digital model. The medium of supporting equipment for construction works is still inadequate, such as a mapping survey laboratory which is an important part of the field data of construction work. Complete mapping survey service providers can be an alternative for users who want to use mapping survey services for both consultants and contractors in East Kalimantan Province.

The establishment of mapping survey laboratory in Samarinda City to support construction work in East Kalimantan Province which of course needs high enough cost, so that feasibility study analysis needs to be done for the development of mapping survey laboratory in Samarinda City. The establishment of mapping survey laboratory in Samarinda city as supporting facility for work construction is expected to serve with the fast timing of 
survey mapping service needs in East Kalimantan. In investment activities, it must pay attention on some business supporting aspects to gain maximal profit and to know whether the business is feasible or not, such as: market aspect; if the market or the consumers enjoying this product service is not that many, then this business market is not feasible, (Brook, 2016). The second is management aspect: who undergoes those aspects; social aspect: how is the implication for people surrounding the project; and the finance aspect.

The establishment of a mapping survey laboratory is considered as a supporting facility for construction works. Problems to be reviewed in this research include: 1) how much investment cost of mapping survey laboratory establishment needed in Samarinda City?, 2) how much cost and benefit of mapping survey laboratory establishment in Samarinda City?, 3 ) is the mapping survey laboratory establishment feasible in Samarinda City?.

From the problems above, this research has objectives such as: 1) Analyzing the investment cost of mapping survey laboratory establishment in Samarinda City, 2) Analyzing the cost and benefit value of mapping survey laboratory establishment in Samarinda City, 3) Analyzing whether it is feasible or not to establish a mapping survey laboratory in Samarinda City.

\section{LITERATURE REVIEW}

Definition of Feasibility Study. Every proposal or project plan must firstly be evaluated for feasibility in various aspects including technical feasibility, operational feasibility, economic feasibility, and so forth. The project feasibility study is a study of whether a project (usually an investment) is able to be conducted successfully or not. This notion of success may be interpreted in a more limited sense, also interpreted more broadly. In a more limited sense, it is especially used by private parties who are more interested in the economic benefits of an investment. Whereas, from the government, or nonprofit, being profitable meaning can be in a more relative sense. It may be considered various factors such as benefits for the wider community that could be the employment, the abundant resource utilization in the place, and so on. It can also be associated with, for example, savings in foreign exchange or additional foreign exchange needed by the government, (Effendi, 2009). In general, a project feasibility study will involve three aspects:

- The project economic benefits are for the project itself (financial benefits). It means that whether the project is viewed quite profitable when compared to project risk;

- The project economic benefits are for the country where the project is implemented (national economic benefits). It shows the benefits of the project for a country's macro economy;

- The project social benefits are for the communities surrounding the project.

Definition of Investment. Investment is the attribution of sources in long term to gain profits in the future (Mulyadi, 2001). Investment can also be defined as capital investing or ownership of long-term sources that will be profitable in some future accounting periods (Supriyono, 1987). Besides, investment can also be defined as the placement of the current amount of funds in the hope of making a profit in the future (Halim, 2005). According to Husnan and Suwarsono (2008), investment is to maximize the values of market and capital themselves. The capital owners themselves are the companies that should attempt to improve their welfare. Many advantages that can be obtained from investment activities, such as: employment, resulted output increase, exchange saving or exchange addition. Basically, the increase of investment activities can trigger and motivate the economic activities in a country. Absolutely, the intended investment activities are the investment activities that invite loss for associated parties in the future.

Definition of Mapping Survey Laboratory. Laboratory (abbreviated as lab) is where scientific research, experiment, measurement or scientific training is done. Laboratory is typically built to enable the conduct of these activities in a controlled manner. Meanwhile, according to Emha (2002), the laboratory is defined as a place to conduct experiments, investigations, and so on that relate to physics, chemistry, and biology or other fields. Another definition is sounded by Sukarso (2005), the laboratory is a place where work 
activities to produce something. This place can be a closed room, room, or open space, such as gardens, and so forth.

Based on the afore-mentioned definitions, a laboratory is a place used for experiments or training related to physics, biology, and chemistry or other fields of science, which is a closed room, room, or open space like gardens and others.

Survey or surveying is defined as collecting data related to earth surface measurements and illustrated by map or digital. While the measurement is defined as equipment and methods related to the continuity of the survey. So, surveying is everything related to data collection. It is started from the measurement of the earth's surface to the depiction of the earth's shape. Besides, a measurement is everything related to the use of tools ranging from measuring tapes to distance measurements with electromagnetic methods.

Survey is generally done on a flat field, which is by not taking into account the curvature of the earth. In a surveying project, the curvature of the earth is small, so the effect can be neglected by using calculations which its formulas are simplified. On the other hand, a project that has a long distance, the curvature of the earth cannot be neglected because this situation includes geodesy surveying.

The Mapping Survey is defined as a science, arts, and technology to determine relative positions, upper points, or beneath the surface of the earth. In a more general sense, survey (geomatics) can be defined; a discipline that encompasses all methods of measuring and collecting information about the earth's physical and the environment; processing information, and disseminating various products produced for various needs, (Nihtinen et al, 2007).

At the moment, the role of our environmental measurements and monitoring is becoming increasingly important, due to the increase of human population, the rising prices of land, the diminishing of our natural resources, and the human activity that causes our soil, water, and air quality decline. In modern age like nowadays, with the help of computer and satellite surveyor technology, the earth and natural resources globally can be measured and monitored. Much information has been available like; Making planning decisions, and formulating policies in various land use resource development, and environmental conservation applications.

\section{METHODS OF RESEARCH}

The type of research used in this research is qualitative with case study approach because its research produces descriptive data which discuss about investment feasibility assessment using Net Present Value (NPV) method, Internal Rate Return (IRR), Benefit Cost Ratio (BCR), and Pay Back Period (PBP). The data used in the analysis, aiming to be able to make a conclusion in this study, consist of primary data and secondary data. Primary data is data obtained directly from the source, observed and recorded for the first time. Secondary data is the data collected by researchers themselves. Secondary data used in this research is data of the number of project, which is the amount of survey service use assumption at infrastructure project activity in East Kalimantan 2015 on General Plan of Procurement at Department of Public Works of East Kalimantan Province. In this study, primary data collection is obtained by conducting questions and answers to the concerned parties. While, the secondary data is obtained through literature or literature study which is by reading and studying books related to this writing and through the documentary which is by reading the reports issued by relevant agencies. The data has been collected and then moved into the work table to facilitate the classification and data code and to facilitate the stages of data analysis.

\section{RESULTS OF STUDY}

Investment. Total Investment Cost for Mapping Survey Laboratory Establishment is Rp. $11,619,400,000.00$. For more details, it can be seen in the following table: 
Table 1 - Investment Cost of Mapping Survey Laboratory Establishment

\begin{tabular}{|c|l|c|c|c|c|}
\hline No. & \multicolumn{1}{|c|}{ Type of Investment } & Unit & Quantity & Unit price (Rp) & Price (Rp) \\
\hline 1 & Land Procurement & $\mathrm{M}^{2}$ & 300 & $3,500,000.00$ & $1,050,000,000.00$ \\
\hline 2 & Construction of a 3-storey Lab & $\mathrm{M}^{2}$ & 600 & $5,000,000.00$ & $3,000,000,000.00$ \\
\hline 3 & Office Equipment and Furniture & Set & 1 & $250,000,000.00$ & $250,000,000.00$ \\
\hline 4 & Mapping Survey Equipment & Set & 1 & $6,000,000,000.00$ & $6,000,000,000.00$ \\
\hline 5 & Operational car & Nos & 2 & $450,000,000.00$ & $900,000,000.00$ \\
\hline 6 & Generator (10 KVA) & Nos & 1 & $70,000,000.00$ & $70,000,000.00$ \\
\hline 7 & Motorcycle & Nos & 3 & $22,000,000.00$ & $66,000,000.00$ \\
\hline 8 & Other cost 2.5\% & - & - & $283,400,000.00$ \\
\hline \multicolumn{4}{|c|}{ Total } \\
\hline
\end{tabular}

Analysis of Net Present Value (NPV). Analysis in the use of Net Present Value (NPV) method obtains a value of Rp. 1,964,475,890, so that the establishment of a mapping survey laboratory is feasible. The calculation of investment feasibility analysis is by using Net Present Value (NPV) method with interest rate of $12 \%$ by calculating investment age of 10 years. This information can be seen in detail in the following table.

Table 2 - Calculation of Net Present Value (NPV) Method

\begin{tabular}{|c|c|c|c|}
\hline Years & Net Benefit (Rp.) & DF 12\% & Present Value (Rp.) \\
\hline 2016 & $-11,619,400,000$ & 1.0000 & $-11,619,400,000$ \\
\hline 2017 & $1,071,725,203$ & 0.8929 & $956,897,503$ \\
\hline 2018 & $1,094,146,203$ & 0.7972 & $872,246,654$ \\
\hline 2019 & $1,336,302,203$ & 0.7118 & $951,153,513$ \\
\hline 2020 & $1,569,620,453$ & 0.6355 & $997,522,174$ \\
\hline 2021 & $1,945,388,422$ & 0.5674 & $1,103,865,635$ \\
\hline 2022 & $2,005,353,113$ & 0.5066 & $1,015,974,296$ \\
\hline 2023 & $2,684,014,004$ & 0.4523 & $1,214,111,629$ \\
\hline 2024 & $3,048,775,084$ & 0.4039 & $1,365,349,122$ \\
\hline 2025 & $3,785,626,694$ & 0.3606 & $3,875,620,427$ \\
\hline 2026 & $12,037,088,758$ & 0.3220 & $1,964,475,890$ \\
\hline \multicolumn{2}{|r|}{} \\
\hline
\end{tabular}

Analysis of Internal Rate Return (IRR). Internal Rate Return Criteria (IRR) in the establishment of this mapping survey laboratory obtains interest rate of $13.37 \%$ which is higher than $12 \%$ discount factor, so it is feasible to be conducted.

Table 3 - Calculation of Internal Rate Return Method

\begin{tabular}{|c|c|c|c|c|c|}
\hline Years & Net Benefit (Rp.) & DF 12\% & Present Value (Rp.) & DF 14\% & Present Value (Rp.) \\
\hline 2016 & $-11,619,400,000$ & 1.0000 & $-11,619,400,000$ & 1.0000 & $-11,619,400,000$ \\
\hline 2017 & $1,071,725,203$ & 0.8929 & $956,897,503$ & 0.8772 & $940,109,827$ \\
\hline 2018 & $1,094,146,203$ & 0.7972 & $872,246,654$ & 0.7695 & $841,909,975$ \\
\hline 2019 & $1,336,302,203$ & 0.7118 & $951,153,513$ & 0.6750 & $901,965,924$ \\
\hline 2020 & $1,569,620,453$ & 0.6355 & $997,522,174$ & 0.5921 & $929,341,313$ \\
\hline 2021 & $1,945,388,422$ & 0.5674 & $1,103,865,635$ & 0.5194 & $1,010,373,786$ \\
\hline 2022 & $2,005,353,113$ & 0.5066 & $1,015,974,296$ & 0.4556 & $913,611,902$ \\
\hline 2023 & $2,684,014,004$ & 0.4523 & $1,214,111,629$ & 0.3996 & $1,072,632,170$ \\
\hline 2024 & $3,048,775,084$ & 0.4039 & $1,231,349,122$ & 0.3506 & $1,068,775,712$ \\
\hline 2025 & $3,785,626,694$ & 0.3606 & $1,365,134,937$ & 0.3075 & $1,164,110,277$ \\
\hline 2026 & $12,037,088,758$ & 0.3220 & $3,875,620,427$ & 0.2697 & $3,246,930,177$ \\
\hline \multicolumn{7}{|r}{} & $=$ & $1,964,475,890$ & & $470,361,063$ \\
\hline
\end{tabular}

$$
\begin{gathered}
\mathrm{IRR}=\mathrm{DF} 1+\frac{\mathrm{NPV} 1}{\mathrm{NPV} 1-\mathrm{NPV} 2} \times(\mathrm{DF} 2-\mathrm{DF} 1)=12 \%+\frac{1,964,475,890}{1.964 .475,890-470,361,063} \times(14 \%-12 \%) \\
=12 \%+\frac{1,964,475,890}{1,494,114,827} \times 2 \%=12 \%+1,37 \%=13.37 \% / \text { Year }
\end{gathered}
$$


Analysis of Benefit Cost Ratio (BCR). In the calculation of Benefit Cost Ratio (BCR), it obtained value of 1.962 which is more than 1 , then the establishment of this mapping survey laboratory is feasible.

Table 4 - Calculation of Benefit Cost Ratio (BCR) Method

\begin{tabular}{|c|c|c|c|c|c|c|c|}
\hline Years & Investment & $\begin{array}{l}\text { Operational } \\
\text { costs (Rp.) }\end{array}$ & Benefit (Rp.) & DF $12 \%$ & I. (Rp.) & OM (Rp.) & B (Rp.) \\
\hline 2016 & $11,619,400,000$ & 0 & 0 & 1 & $11,619,400,000$ & 0 & 0 \\
\hline 2017 & 0 & $1,071,825,000$ & $4,200,000,000$ & 0.8929 & 0 & $956,986,607$ & $3,750,000,000$ \\
\hline 2018 & 0 & $1,259,404,000$ & $4,410,000,000$ & 0.7972 & 0 & $1,003,989,158$ & $3,515,625,000$ \\
\hline 2019 & 0 & $1,347,998,000$ & $4,740,750,000$ & 0.7118 & 0 & $959,478,350$ & $3,374,372,210$ \\
\hline 2020 & 0 & $1,470,236,000$ & $5,096,306,250$ & 0.6355 & 0 & $934,361,558$ & $3,238,794,755$ \\
\hline 2021 & 0 & $1,476,691,000$ & $5,478,529,219$ & 0.5674 & 0 & $837,914,131$ & $3,108,664,609$ \\
\hline 2022 & 0 & $1,827,616,000$ & $5,889,418,910$ & 0.5066 & 0 & $925,927,143$ & $2,983,762,906$ \\
\hline 2023 & 0 & $1,737,897,000$ & $6,478,360,801$ & 0.4523 & 0 & $786,136,344$ & $2,930,481,425$ \\
\hline 2024 & 0 & $2,020,972,000$ & $7,126,196,881$ & 0.4039 & 0 & $816,236,695$ & $2,878,151,400$ \\
\hline 2025 & 0 & $2,174,895,000$ & $8,016,971,491$ & 0.3606 & 0 & $784,288,940$ & $2,891,000,290$ \\
\hline 2026 & 0 & $2,384,818,000$ & $9,019,092,928$ & 0.3220 & 0 & $767,847,570$ & $2,903,906,541$ \\
\hline \multicolumn{5}{|c|}{ Total } & $11,619,400,000$ & $8,773,166,497$ & $31,574,759,134$ \\
\hline
\end{tabular}

The calculation of Benefit Value minus by the value of Operations and Maintenance is as below:

$$
\mathrm{BCR}=\frac{\mathrm{PV} \text { Benefit }}{\mathrm{PV} \text { Cost }}=\frac{\text { Total Benefit }- \text { Total Operational Maintenance }}{\text { Investment }}=\frac{31,574,759,134-8,773,166,497}{11,619,400,000}=1.962
$$

Analysis of Pay Back Period (PBP). With the calculation of Pay Back Period (PBP), the establishment of this mapping survey laboratory resulted 4 Years 8 Months relatively nearly half of the investment period of 10 years.

$$
\mathrm{PBP}=T_{p-1}+\frac{\sum_{i=1}^{n} I_{i}-\sum_{i=1}^{n} B_{i c p-1}}{B_{p}}=4+\frac{1,595,42,309}{67532,669-1,595,42,30}=4+0.70=4+8 \text { months }
$$

Table 5 - Calculation of Pay Back Period (PBP) Method

\begin{tabular}{|c|c|c|c|c|c|}
\hline Years & I. (Rp.) & OM (Rp.) & B (Rp.) & Net Benefit (Rp.) & Cumulative Benefit (Rp.) \\
\hline 2016 & $11,619,400,000$ & 0.0000 & 0 & $-11,619,400,000$ & $-11,619,400,000$ \\
\hline 2017 & 0 & $956,986,607$ & $3,750,000,000$ & $2,793,013,393$ & $-8,826,386,607$ \\
\hline 2018 & 0 & $1,003,989,158$ & $3,515,625,000$ & $2,511,635,842$ & $-6,314,750,765$ \\
\hline 2019 & 0 & $959,478,350$ & $3,374,372,210$ & $2,414,893,859$ & $-3,899,856,906$ \\
\hline 2020 & 0 & $934,361,558$ & $3,238,794,755$ & $2,304,433,197$ & $-1,595,423,709$ \\
\hline 2021 & 0 & $837,914,131$ & $3,108,664,609$ & $2,270,750,478$ & $675,326,769$ \\
\hline 2022 & 0 & $925,927,143$ & $2,983,762,906$ & $2,057,835,762$ & $2,733,162,531$ \\
\hline 2023 & 0 & $786,136,344$ & $2,930,481,425$ & $2,144,345,081$ & $4,877,507,612$ \\
\hline 2024 & 0 & $816,236,695$ & $2,878,151,400$ & $2,061,914,705$ & $6,939,422,317$ \\
\hline 2025 & 0 & $784,288,940$ & $2,891,000,290$ & $2,106,711,350$ & $9,046,133,666$ \\
\hline 2026 & 0 & $767,847,570$ & $2,903,906,541$ & $2,136,058,971$ & $11,182,192,637$ \\
\hline & $11,619,400,000$ & $8,773,166,497$ & $31,574,759,134$ & $11,182,192,637$ & $3,197,927,546$ \\
\hline
\end{tabular}

\section{DISCUSSION OF RESULTS}

Investment of this mapping survey laboratory establishment used is sourced from bank loan funds amounting to Rp.11,619,400,000.00. The discussion of this investment cost assumption that will be explicated is related to the elements in the calculation of mapping survey laboratory establishment in Samarinda. It can be seen in the table of Investment Cost of Mapping Survey Laboratory Establishment.

Land Procurement Cost. In this investment, the alternative of location that will established is a strategic location, so that the users of mapping survey services in the field of construction can easily get to the location of the mapping survey laboratory. Based on the market price of land located in the site, it is between $3-3.5$ million rupiah/M2, then it is 
assumed that the highest value is taken with consideration to obtain the strategic location. With a land area of $300 \mathrm{M} 2$, then the cost of land procurement is Rp. 1.050.000.000,-.

Establishment of Mapping Survey Laboratory. The investment of this mapping survey laboratory establishment is made with the assumption that the building will be occupied to be built itself which its construction is given by the contractors at a cost of Rp. 3.000.000.000,-It is as in the table below which is a recapitulation of Cost Budget Plan of Mapping Survey Laboratory Establishment.

Office Equipment and Furniture. With the establishment of this mapping survey laboratory, then office equipment and furniture are also required to support the laboratory activities. The purchase of office equipment and furniture is Rp.250.000.000,- which is counted as a set for the whole building.

Mapping Survey Equipment. The equipment needed in the establishment of this mapping survey laboratory is the main element because the existing equipment must support the services provided to the consumers, with various types of equipment such as manual type, semi digital type and full digital type and all equipment is the latest equipment in the aspect of technology, so that consumers are expected to have construction services that will ultimately provide a great income. The price for the purchase of equipment of all types needed is Rp. 6.000.000.000,--.

Operational Car. In supporting the activities of outside mapping survey laboratory, then vehicle that can be used in all fields is needed, therefore the selected vehicle is Double Cabin Car which is assumed to price of Rp.450.000.000,- per unit and the total purchase for 2 vehicles is $\mathrm{Rp}$. 900.000.000,-

Generator. Circumstances in the city of Samarinda which is often occurring a power outage is the reason for the purchase of a unit of generator with a capacity of 10 KVA for activity in Mapping Survey Laboratory keeps running, so that the service to consumers is not disturbed. Purchase of one unit generator with the price of Rp.70.000.000, -

Motorcycle. To support the activity in the mapping survey laboratory, two-wheeled vehicles are needed for the benefit of relatively close employee mobility and no need to use the car. The purchase price of 3 units of two-wheeled vehicles is Rp. 66.000.000,-

Other Costs. In this investment cost, it is needed funds that may not be known yet the amount of the price, then $2.5 \%$ is taken from Investment Cost as other costs, thus it is obtained Rp. 283.400.000,--.

Calculation of Cost and Benefit. Total Cost of Investment + Operational Cost + Bank Loan (Principal Loans + Bank Interest) from 2016 to 2026 is Rp.20.392.566.497,20. Annual operational costs are calculated with several approaches, including:

Operational Cost of Mapping Survey Laboratory, covering fuel cost of operational vehicle and generator of Rp. 9.990.000,00/month.

Personnel costs, including personnel costs are burdened by employee salary of Rp 31.250.000,00/month and by Laboratory fixed employees salary of Rp.24.000.000,00/month. While, for some components related to employee activities, it is assumed as follows: Employee overtime of $2.5 \%$ from employee's salary; Holiday allowance of 1 month from employee's salary; Employee bonus of $1.5 \%$ from employee's salary;Welfare and other employee expenses of $1 \%$ for each employee's salary.

Maintenance costs in operational laboratory consisting of laboratory equipment maintenance, operational vehicle maintenance amounting to Rp.242.995.000/year.

General administrative costs, including in office stationery, office household needs, photocopy and printed materials, correspondence, electricity and telephone amounting to Rp. 5.900.000,00/month.

From the above details, the operational cost of the project in 2017 is Rp. 1.071.825.000,00/year.

In the calculation of this expenditure costs, it also calculates the increase of each year, such as: Assumption of Fuel Increase $=2 \%$ per Year; Assumption of Increase Spare parts = $2 \%$ per Year; Assumption of Employee Salary Increase $=10 \%$ per Year; Assumption of Maintenance Increase $=5 \%$ per year; Assumption of Other Increases $=2 \%$ per Year. 
The profit of this mapping survey laboratory establishment is by calculating net benefit obtained from Benefit minus Investment Cost and Operational Cost + Maintenance, then it is obtained the calculation as in the following table.

Table 6 - Calculation of Profitability Ratio

\begin{tabular}{|c|c|c|c|c|c|}
\hline Years & Investment & $\begin{array}{c}\text { Operational } \\
\text { Maintenance }\end{array}$ & Benefit & Net Benefit & Cumulative Benefit \\
\hline 2016 & $11,619,400,000.00$ & 0.00 & 0.00 & $-11,619,400,000.00$ & $-11,619,400,000.00$ \\
\hline 2017 & 0.00 & $956,986,607.14$ & $3,750,000,000.00$ & $2,793,013,392.86$ & $-8,826,386,607.14$ \\
\hline 2018 & 0.00 & $1,003,989,158.16$ & $3,515,625,000.00$ & $2,511,635,841.84$ & $-6,314,750,765.31$ \\
\hline 2019 & 0.00 & $959,478,350.49$ & $3,374,372,209.82$ & $2,414,893,859.33$ & $-3,899,856,905.98$ \\
\hline 2020 & 0.00 & $934,361,557.52$ & $3,238,794,754.96$ & $2,304,433,197.44$ & $-1,595,423,708.54$ \\
\hline 2021 & 0.00 & $837,914,131.00$ & $3,108,664,608.56$ & $2,270,750,477.56$ & $675,326,769.02$ \\
\hline 2022 & 0.00 & $925,927,143.16$ & $2,983,762,905.54$ & $2,057,835,762.37$ & $2,733,162,531.40$ \\
\hline 2023 & 0.00 & $786,136,344.29$ & $2,930,481,425.08$ & $2,144,345,080.79$ & $4,877,507,612.19$ \\
\hline 2024 & 0.00 & $816,236,695.02$ & $2,878,151,399.63$ & $2,061,914,704.62$ & $6,939,422,316.81$ \\
\hline 2025 & 0.00 & $784,288,940.28$ & $2,891,000,289.81$ & $2,106,711,349.53$ & $9,046,133,666.33$ \\
\hline 2026 & 0.00 & $767,847,570.14$ & $2,903,906,541.10$ & $2,136,058,970.96$ & $11,182,192,637.30$ \\
\hline Total & $11,619,400,000$ & $8,773,166,497$ & $31,574,759,134$ & $11,182,192,637.30$ & $3,197,927,546.09$ \\
\hline
\end{tabular}

All in Rupiah.

Data Source: Analysis Results.

The average benefit calculation per year is Rp. 2,280,159,263.73 by not included in the first year. At Cumulative Profit Value, then it is got Rp. 3,197,927,546.09 until the end of investment. The residual value of the land and buildings and equipment is 7.459.263.627,38 which is also included in the calculation of the total profit, so that the profit value of Benefit from Selling Price + Residual Value to 2026 is Rp. 18.641.456.264,67.

Investment Feasibility of Mapping Survey Laboratory Establishment. The calculation of financial aspect in analyzing investment feasibility of this Mapping Survey Laboratory Establishment is summarized as shown in the table below

Table 7 - NPV, IRR, BCR, PBP

\begin{tabular}{|c|c|}
\hline NPV & Rp. 1964475890 \\
\hline IRR & $13.37 \%$ \\
\hline BCR & 1,962 \\
\hline PBP & 4 Years 8 Months \\
\hline
\end{tabular}

NPV Net Present Value Method. Net Present Value (NPV) Method with interest rate of $12 \%$ with 10 years investment obtained NPV calculations which its results are positive amounting to $1,964,475,890$, thus the establishment of mapping survey laboratory is feasible to do.

IRR Internal Rate Return Method. Calculation by IRR Internal Rate Return method that obtains $13.37 \%$ higher than discount factor level which is $12 \%$, then Establishment of Mapping Survey Laboratory is feasible.

$B C R$ Benefit Cost Ratio Method. In the calculation of BCR, it obtained value of 1.962 higher than 1, then the establishment of Mapping Survey Laboratory Establishment is feasible.

PBP Pay Back Period Method. In the calculation of PBP, it results 4 Years 8 Months which is relatively close to half the age of the investment which is 10 Years, then the establishment of Mapping Survey Laboratory is feasible.

\section{CONCLUSION}

The investment value of Mapping Survey Laboratory Establishment in Samarinda City is Rp. $11,619,400,000.00$ done in 1 year that is in year of 2016. In the calculation, it is obtained total cost and benefits as follows: a) total Cost of Investment + Operational Cost + 
Bank Credit (Principal Loans + Interest Bank) until 2026 is Rp. 20.392.566.497,20, b) benefit from the price of the service until 2026 is Rp.31.574.759.134,50. The Establishment of Mapping Survey Laboratory is economically feasible to build, with economic analysis as follows: a) Net Present Value Value> 0 is Rp. 1.964.475,890, b) Internal Rate of Return> $12 \%$ is $13,37 \%$, c) Benefit Cost Ratio $>1$ is 1.962 , d) Pay Back Period (PBP) is 4 Years 8 Months.

\section{REFERECES}

1. Abdul Halim, (2005). Analisis Investasi, Edisi Ke-2. Salemba Empat, Jakarta.

2. Brook, M. (2016). Estimating and tendering for construction work. Taylor \& Francis.

3. Buchholz, B., Paquet, V., Punnett, L., Lee, D., \& Moir, S. (1996). PATH: a work samplingbased approach to ergonomic job analysis for construction and other non-repetitive work. Applied ergonomics, 27(3), 177-187.

4. Effendi, H, (2009). Analisis Kelayakan pembangunan Asphalt Mixing Plant (AMP) di Pulau Kangean Kabupaten Sumenep, Tesis, UNTAG Surabaya.

5. Emha, H. (2002). Pedoman Penggunaan Laboratorium Sekolah. PT Remaja Roesda Karya, Bandung.

6. Husnan, S. dan Suwarsono, M. 2008. Studi Kelayakan Proyek,UPP AMP YKPN. Yogyakarta.

7. Mulyadi, (2001). Akuntansi Manajemen: Konsep, Manfaat dan Rekayasa, Edisi. Ketiga. Salemba Empat. Jakarta.

8. Nihtinen, A., Anttila, V. J., Richardson, M., Meri, T., Volin, L., \& Ruutu, T. (2007). The utility of intensified environmental surveillance for pathogenic moulds in a stem cell transplantation ward during construction work to monitor the efficacy of HEPA filtration. Bone marrow transplantation, 40(5), 457.

9. Sukarso, 2005, Pengertian dan Fungsi Laboratorium. Online http://wanmustafa.wordpress.com/2011/06/12/pengertian-danfungsi-laboratorium/

10. Supriyono, 1987, Akuntansi Biaya: Pengumpulan Biaya dan Penentuan Harga. Pokok Produk. Edisi Kedua.BPFE Universitas Gajah Mada, Yogyakarta. 